\title{
PEMANFAATAN KAIN PERCA UNTUK PEMBUATAN MASKER KAIN (MAIN) ANTI VIRUS DALAM RANGKA PENCEGAHAN VIRUS COVID 19 PADA RUMAH JAHIT SEKITARAN MEDAN JOHOR
}

\section{THE UTILIZATION OF PERCA FABRIC TO MAKE ANTI VIRUS FABRIC MASK AS A PREVENTION OF COVID 19 VIRUSES IN SEWING HOUSE AROUND MEDAN JOHOR}

\author{
Wardiyah Daulay $^{1}$, Mahnum Lailan Nasution ${ }^{2}$, Sri Eka Wahyuni $^{3}$ \\ ${ }_{1,2,3}$ Universitas Sumatera Utara \\ email: wardiyah_daulay@yahoo.co.id
}

\begin{abstract}
The number of cases of the Covid-19 virus in Indonesia, especially Medan, has increased. Almost every day the number of PDP (Patients under Supervision) or positive patients continues to increase. Medan city has set an emergency status for the corona Covid-19 virus since Mid-March and Medan Johor district sice early April has been designated as one of the sub-districts with the status of the Red Zone. To minimize its spread, the government is promoting a "Mask for ALL" program. The program is in line with the appeal of the centers for disease control and prevention, which recommends wearing masks for everyone who want to leave the house. Due to limited number of masks that are ideal for preventing the corona virus, cloth masks can also used as an option to protect against exposure to the corona virus. This is considered better than not wearing a mask at all when coughing and sneezing or when near other people who may have been infected with the corona virus. Fabric masks can be produced by sewing houses by using the patchwork they have. Becauses the materials in making masks do not require a lot of material, patchwork can be used and people who have sewing houses are also helped in the corona pandemic.
\end{abstract}

Keywords: Covid-19, Masks, Patchwork

\section{abstrak}

Angka penyebaran kasus virus covid-19 di Indonesia khususnya Kota Medan mengalami peningkatan. Hampir setiap hari jumlah PDP (Pasien Dalam Pengawasan) ataupun pasien positif terus bertambah. Kota Medan menetapkan status siaga darurat virus Corona COVID-19 sejak pertengahan Maret dan Kecamatan Medan Johor sejak awal April telah ditetapkan sebagai salah satu kecamatan yang berstatus Red Zone. Untuk meminimalisir penyebarannya maka pemerintah menggalakkan program 'masker untuk semua'. Program tersebut senada dengan imbauan Pusat Pengendalian dan Pencegahan Penyakit, yang menganjurkan untuk memakai masker bagi semua orang yang hendak keluar rumah. Karena keterbatasan jumlah masker yang ideal untuk mencegah virus Corona, masker kain pun bisa dijadikan pilihan untuk melindungi dari paparan virus Corona. Hal ini dianggap lebih baik daripada tidak mengenakan masker sama sekali ketika batuk dan bersin atau ketika berdekatan dengan orang lain yang mungkin sudah terinfeksi virus Corona. Masker kain dapat diproduksi oleh rumah jahit dengan memnfaatkan kain perca yang dimilikinya. Karena bahan dalam pembuatan masker tidak membutuhkan bahan yang banyak, sehingga kain perca dapat digunakan dan masyarakat yang memiliki rumah jahit juga terbantu dalam kondisi pandemi corona.

Kata Kunci: Covid-19, Kain Perca, Masker 


\section{PENDAHULUAN}

Corona virus adalah keluarga besar virus yang menyebabkan penyakit mulai dari gejala ringan sampai berat. Coronavirus 2019 (COVID-19) adalah penyakit jenis baru yang belum pernah diidentifikasi sebelumnya pada manusia. Tanda dan gejala umum infeksi COVID-19 antara lain gejala gangguan pernapasan akut seperti demam, batuk dan sesak napas. Pada kasus COVID-19 yang berat dapat menyebabkan pneumonia, sindrom pernapasan akut, gagal ginjal, dan bahkan kematian.

Pada 31 Desember 2019, WHO China Country Office melaporkan kasus pneumonia yang tidak diketahui etiologinya di Kota Wuhan. Penyebaran kasus di Indonesia khususnya kota Medan mengalami hal yang sama. Hampir setiap hari jumlah PDP (Pasien Dalam Pengawasan) ataupun pasien positif terus bertambah. Kota Medan sendiri, menetapkan status siaga darurat virus Corona COVID-19 sejak tanggal 16 Maret 2020. Hal tersebut disampaikan oleh Plt Wali Kota Medan Akhyar Nasution saat memimpin rapat koordinasi dalam rangka upaya pencegahan dini dan penularan serta minimalisir penyebaran COVID-19 di Kota Medan di Ruang Rapat III, Balai Kota Medan.

Kecamatan Medan Johor sejak awal April telah ditetapkan sebagai salah satu kecamatan yang berstatus Red Zone. Guna meminimalisir penyebarannya maka dilakukan penangguhan kegiatan belajar mengajar, ibadah, kegiatan bisnis yang melibatkan kerumunan dan membatasi perjalanan kecuali yang mendesak dan penting. Kecamatan Medan Johor ini merupakan wilayah padat pemukiman penduduk yang sebagian besar penduduknya berwiraswasta. Beberapa perumahan menengah ke atas berada di wilayah ini dan dihuni oleh pengusaha dan pejabat yang kemungkinan punya akses ke luar kota bahkan keluar negeri dalam pekerjaannya.

Pandemi corona telah membuat sebagian masyarakat mengalami penurunan omset termasuk para penjual jasa seperti tukang jahit. Mereka yang biasanya setiap hari menerima order jahitan 10 sampai 20 perhari, saat ini terimbas sehingga dalam satu hari terkadang tidak ada sama sekali orderan. Untuk menjahit satu buah pakaian biasanya menghasilkan limbah perca yang tidak dapat dipergunakan lagi. Dan biasanya perca yang kecil akan dibuang dan sama sekali tidak dipakai. Saat ini kain perca tersebt dapat diolah menjadi masker kain karena kebutuhan untuk membuat satu buah masker hanya sedikit dan bisa dimanfaatkan dari kain perca tersebut.

Berdasarkan bukti ilmiah, COVID-19 dapat menular dari manusia ke manusia melalui kontak erat dan droplet. Orang yang paling berisiko tertular penyakit ini adalah orang yang kontak erat dengan pasien COVID-19 termasuk yang merawat pasien COVID-19. Rekomendasi standar untuk mencegah penyebaran infeksi adalah melalui cuci tangan secara teratur, menghindari kontak dekat dengan siapa pun yang menunjukkan gejala penyakit pernapasan dan menerapkan etika batuk dan bersin (Kemenkes 2020). Etika batuk dan bersin yang dianjurkan untuk menghindari penyebaran virus adalah dengan menutup hidung dan mulut dengan tisu saat bersin/batuk atau menggunakan masker yang menutup hidung. Walau disebut kurang efektif dibandingkan jenis masker lain, bukan berarti masker kain tidak layak digunakan sama sekali. Karena keterbatasan jumlah masker yang ideal untuk mencegah virus Corona, masker kain pun bisa dijadikan pilihan untuk melindungi dari paparan virus Corona. 
Hal ini dianggap lebih baik daripada tidak mengenakan masker sama sekali ketika batuk dan bersin atau ketika berdekatan dengan orang lain yang mungkin sudah terinfeksi virus Corona. Awal April yang lalu, juru bicara pemerintah penanganan COVID-19, Achmad Yurianto mengumumkan bahwa pemerintah tengah menggalakkan program 'masker untuk semua'. Program tersebut senada dengan imbauan Pusat Pengendalian dan Pencegahan Penyakit, yang menganjurkan untuk memakai masker bagi semua orang yang hendak keluar rumah. Untuk menghindari terjadinya kelangkaan masker bagi petugas medis dan makin melambungnya harga masker, maka disarankan untuk memilih masker kain. Selain murah, masker kain dapat dicuci, mudah didapat dan dapat dibuat sesuai dengan kepentingannya, misalnya masker karakter kartun untuk anak, laki-laki, wanita berhijab, wanita yang fashionable dengan menambahkan variasi renda.

Penyebaran virus COVID-19 dapat melibatkan masyarakat dalam kesiapsiagaan dan respon untuk menghentikan penyebaran wabah yang semakin meluas serta dapat melindungi individu dan komunitas. Salah satunya dengan pemberdayaan rumah jahit untuk memanfaatkan kain perca yang selama ini tidak dipakai menjadi masker kain (MAIN) yang dapat dipakai oleh masyarakat. Masker kain yang efektif adalah masker yang paling nyaman digunakan sembari bernafas adalah kain kaos katun 100\%, sarung bantal berbahan katun, dan bahan katun pada umumnya. Masker kain ini nantinya dapat dilapis dengan filter kopi atau tisu agar daya saringnya meningkat. setelah melepas masker. Solusi yang diberikan yaitu mengidentifikasi msayarakat yang bersedia membantu pembuatan masker kain dan target yang diharapkan terdapat sekelompok masyarakat yang bersedia, selanjutnya dalam pemilihan bahan perca yang efektif untuk membuat masker diharapkan target yang dicapai terdapat setumpuk kain perca siap olah, pelatihan pembuatan pola dan gunting pola masker diharapkat target yang dicapai meningkatnya pengetahuan dan keterampilan psikomotor penjahit, solusi selanjutnya yaitu dilakukan pelatihan penjahitan masker dan diharapkan peningkatan pengetahuan dan keterampilan psikomotor penjahit, kemudian ketika dilakukan kegiatan pengemasan masker diharapkan masker siap diedarkan dan solusi selanjutnya ketika pendistribusian masker diharapkan target tercapai ketika setiap lingkungan mendapatkan masker.

\section{METODE PENGABDIAN MASYARAKAT}

Metode yang digunakan pada kegiatan pengabdian ini adalah metode pembelajaran langsung (MPL). Model Pembelajaran Langsung (Direct Instruction) merupakan salah satu model pengajaran yang dirancang khusus untuk mengembangkan pengetahuan prosedural dan pengetahuan yang terstruktur dengan baik dan dapat dipelajari selangkah demi selangkah (Amri dkk 2010). Pengetahuan prosedural yang dimaksud dalam pembuatan masker adalah pemilihan bahan, pembuatan pola, pengguntingan pola dan menjahit masker secara terstruktur.

Masker kain berikut adalah masker dengan model tali, cocok dikenakan untuk wanita berhijab. Bahan yang digunakan yaitu 1) Jarum dan benang atau mesin jahit jika ada, 2) Gunting, 3) Peniti atau penjepit untuk menahan kain pada tempatnya, jika tidak ada dapat diganti penjepit kertas, 4) Kain katun, kaos katun yang sudah tidak terpakai, atau sarung bantal katun, 5) Empat strip kain katun untuk pengikat dengan panjang sekitar 45 $\mathrm{cm}$, dapat diganti dengan 4 tali sepatu yang sama panjang.

Cara membuat masker kain yaitu 1) Cuci dan keringkan terlebih dahulu kain agar steril saat digunakan, 2) Ukur panjang kain dan gunting menjadi dua bagian persegi panjang 
dengan ukuran masing-masing sekitar 30x15 cm, 3) Bedakan pola bagian depan dan belakang masker agar tidak mudah tertukar, 4) Tumpuk dua kain persegi panjang, jahit bagian belakang kain menghadap ke depan lalu jahit setiap sisi lapisan hingga kain menyatu, 5) Sisakan sedikit ruang di kedua ujung kain untuk menyelipkan strip kain atau tali sepatu, 6) Selipkan tali pada tiap ujung sisi kain, tahan dengan peniti atau penjepit kertas agar tali tidak bergeser, 7) Jahit seluruh lapisan kain secara backstitch atau jahit berulang agar jahitan lebih kokoh di semua bagian, 8) Masker kain tali siap digunakan (Rafiqua 2020).

\section{HASIL DAN PEMBAHASAN}

Pelaksanaan kegiatan pengabdian masyarakat yang telah dilakukan oleh tim meliputi:

\section{Pengurusan izin kegiatan}

Langkah awal pelaksanaan program pengabdian masyarakat dimulai dengan pengurusan surat tugas dari Lembaga Pengabdian kepada Masyarakat USU dan surat izin dari Fakultas Keperawatan USU. Setelah surat izin didapatkan maka tim pengusul menjumpai pemilik rumah jahit di wilayah Johor.

\section{Mengidentifikasi Masyarakat sebagai Asisten Jahit}

Tahap pertama yang dilakukan adalah melakukan seleksi kepada masyarakat sekitar Rumah Jahit Sania yang akan dilatih untuk membuat masker kain, dengan kriteria mau bekerja sama, memiliki pengetahuan dasar menjahit, memiliki waktu luang dan tidak memiliki indikasi penyakit yang beresiko menular. Dari hasil seleksi didapatkan 10 orang yang bersedia.

\section{Pemilihan Bahan Perca}

Bahan perca yang cocok untuk dijadikan masker kain adalah bahan yang bertekstur halus.
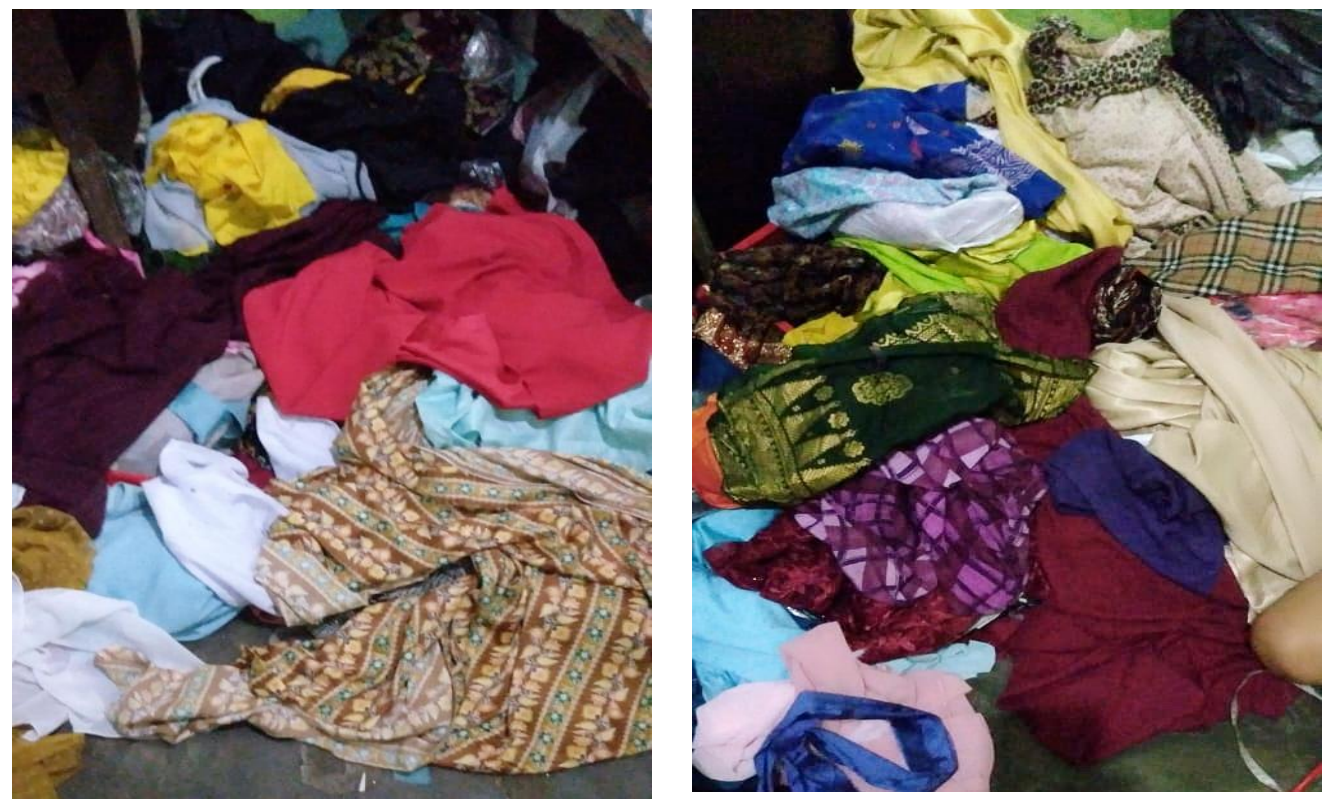

Gambar 1. Pemilihan Bahan Perca 


\section{Pelatihan Pembuatan Pola, Gunting dan Jahit}

Pelatihan dilakukan secara luring dengan protocol pencegahan covid, peserta dilatih dengan waktu yang berbeda.
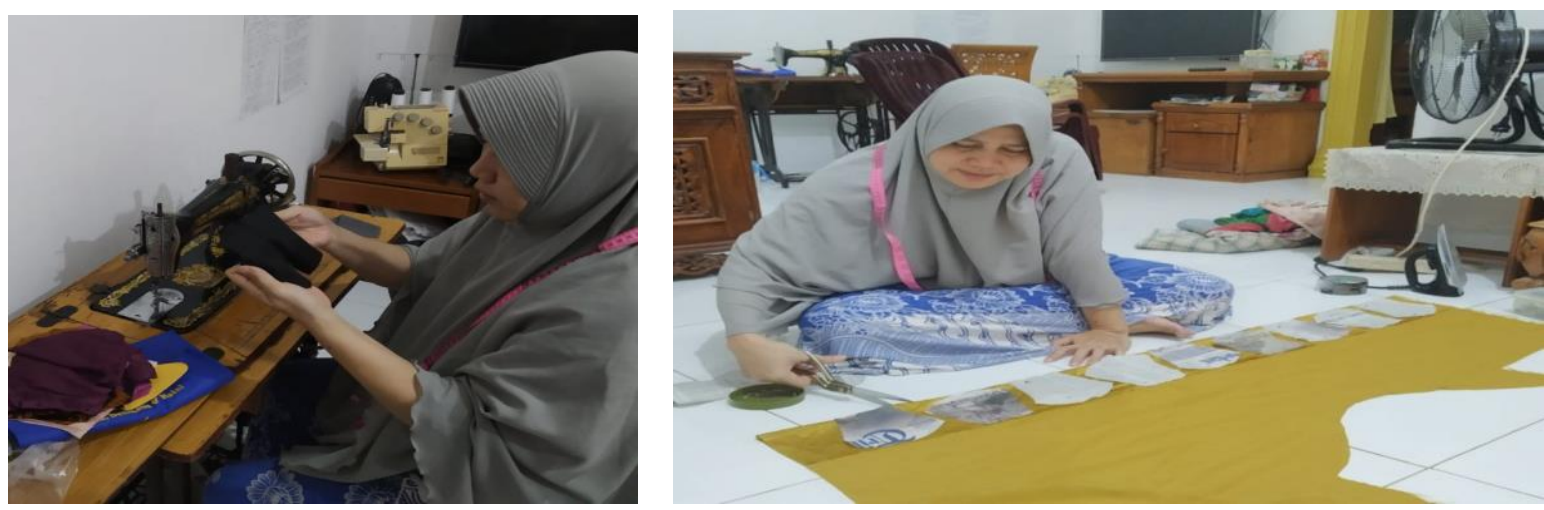

Gambar 2. Pelatihan Pembuatan Pola, Gunting dan Jahit

\section{Pengemasan Masker}

Masker yang telah siap dijahit kemudian dicuci dan digosok terlebih dahulu, baru dilakukan pengemasan agar masker steril dan siap pakai. Pengemasan dengan plastic mika berlem.
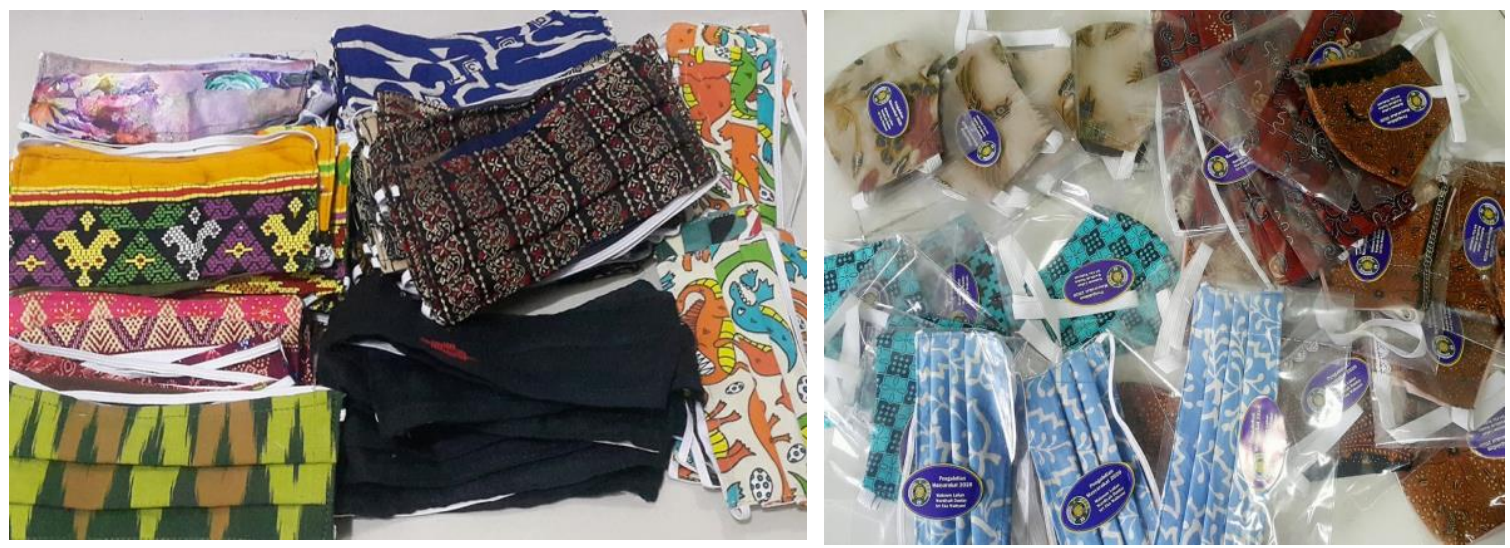

Gambar 3.Pengemasan Masker

\section{Pendistribusian Masker}

Masker dibagi di beberapa tempat di daerah Kecamatan Medan Johor Antara lain masjid saat sholat jumat, pajak, pos satpam perumahan dan jalanan. Sebelum diberikan masker, masyarakat yang bersedia mengisi kuesioner dipersilahkan untuk mengisi melalui perangkat yang telah disediakan oleh tim pelaksana.

Pada perangkat tersebut sudah disediakan kuesioner pengetahuan masyarakat tentang pemakaian masker dalam googleform yang langsung bisa diisi. 

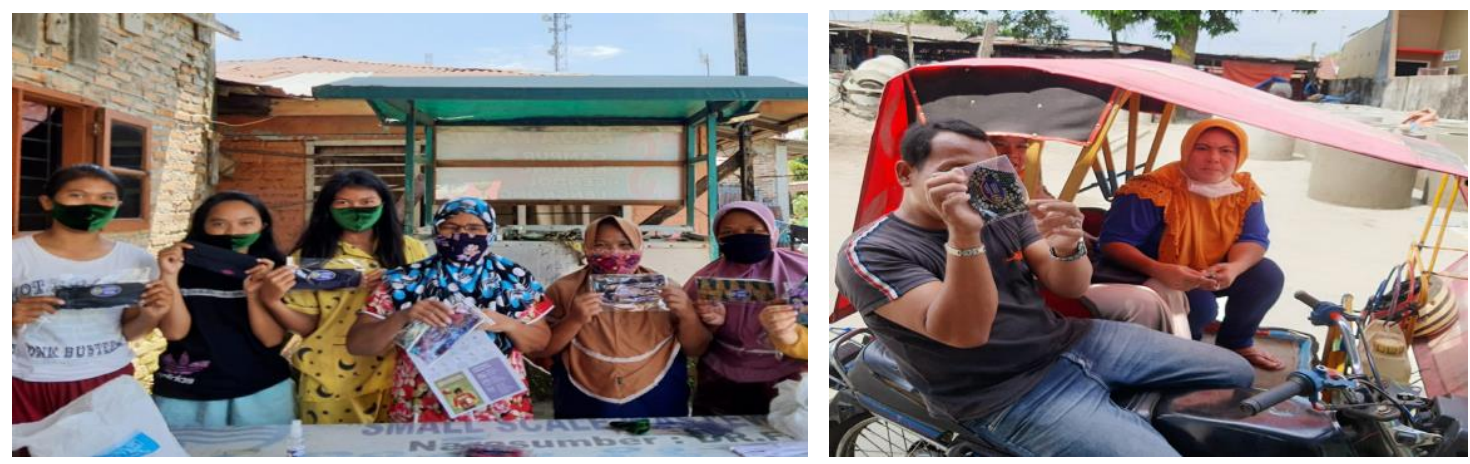

Gambar 4. Pendistribusian Masker

\section{Pengetahuan Masyarakat tentang Pemakaian Masker di Kecamatan Medan Johor}

Pengisian kuesioner dilakukan melalui google form dengan link https://docs.google.com/forms/d/e/1FAIpQLSd2NUGS_GyGEcXhKSe6TG5x_Vv Nd-HScGr54XGhfE3L2mBhNQ/viewform?vc=0\&c=0\&w $=1$

Sampel diambil dengan tekhnik accidental sampling, yaitu masyarakat yang kebetulan ada saat pendistribusian masker dengan kriteria bersedia mengisi link dari perangkat tim pelaksana, masyarakat yang memiliki WA, bisa membaca dan bersedia mengisi link saat distribusi masker dilakukan. Jumlah sampel yang didapat berjumlah 89 orang. Karakteristik demografi dan hasil pengetahuan masyarakat tentang pemakaian masker di Kecamatan Medan Johor dapat dilihat pada tabel 1.

Tabel 1. Karakteristik Demografi Masyarakat Medan Johor $(\mathbf{n}=89)$

\begin{tabular}{lcc}
\hline \multicolumn{1}{c}{ Karakteristik } & Frekuensi (f) & Persentase (\%) \\
\hline Jenis Kelamin & & \\
- Laki-laki & 24 & 27 \\
- Perempuan & 65 & 73 \\
& & \\
Pendidikan & 1 & 1.1 \\
- SD & 13 & 14.6 \\
- SMP & 13 & 14.6 \\
- SMA & 61 & 68.5 \\
- Diploma/Sarjana & 1 & 1.1 \\
- Magister/Doktor & & \\
Usia (Depkes RI, 2009) & 15 & 16.8 \\
- Remaja Awal (12-16 tahun) & 49 & 55.1 \\
- Remaja Akhir (17-25 tahun) & 12 & 13.5 \\
- Dewasa Awal (26-35 tahun) & 5 & 5.6 \\
- Dewasa Akhir (36-45 tahun) & 5 & 5.6 \\
- Lansia Awal (46-55 tahun) & 3 & 3.4 \\
- Lansia Akhir (56-65 tahun) & & \\
$\quad$ &
\end{tabular}

Masyarakat Medan Johor yang dijadikan sampel mayoritas perempuan (73\%), dengan pendidikan Diploma/Sarjana $(68.5 \%)$ dan berada pada rentang usia remaja akhir $(55.1 \%)$. 
Tabel 2. Pengetahuan Masyarakat tentang Pemakaian Masker Kain di Kecamatan Medan Johor $(\mathbf{n}=89)$

\begin{tabular}{|c|c|c|c|}
\hline & Pertanyaan & Jawaban Benar & Jawaban Salah \\
\hline & $\begin{array}{l}\text { Orang Tanpa Gejala Covid-19 } \\
\text { tidak perlu memakai masker }\end{array}$ & $80(89.9 \%)$ & $9(10.1 \%)$ \\
\hline 2. & $\begin{array}{l}\text { Tenaga kesehatan, orang sakit } \\
\text { dan orang yang merawat sakit } \\
\text { sebaiknya menggunakan masker } \\
\text { kain }\end{array}$ & $88(98.9 \%)$ & $1(1.1 \%)$ \\
\hline 3. & $\begin{array}{l}\text { Sebelum memasang masker, } \\
\text { tidak perlu cuci tangan pakai } \\
\text { sabun dan air mengalir }\end{array}$ & $78(87.6 \%)$ & $11(12.4 \%)$ \\
\hline 4. & $\begin{array}{l}\text { Masker dipasang menutup mulut } \\
\text { dan hidung dan pastikan tidak } \\
\text { ada sela antara wajah dan } \\
\text { masker }\end{array}$ & $84(94.4 \%)$ & $5(5.6 \%)$ \\
\hline 4. & $\begin{array}{l}\text { Setelah masker terpasang, } \\
\text { diperbolehkan menyentuh } \\
\text { masker yang sedang dipakai }\end{array}$ & $73(82 \%)$ & $16(18 \%)$ \\
\hline 5. & $\begin{array}{l}\text { Ganti masker yang basah atau } \\
\text { lembab dengan masker yang } \\
\text { baru }\end{array}$ & $89(100 \%)$ & 0 \\
\hline 6. & $\begin{array}{l}\text { Untuk membuka masker, } \\
\text { lepaskan dari belakang dan } \\
\text { jangan sentuh bagian depan } \\
\text { masker }\end{array}$ & $79(88.8 \%)$ & $10(11.2 \%)$ \\
\hline 7. & $\begin{array}{l}\text { Penggunaan masker penting } \\
\text { untuk mencegah penularan } \\
\text { covid-19 }\end{array}$ & $87(98.9 \%)$ & $2(2.2 \%)$ \\
\hline 8. & $\begin{array}{l}\text { Masker kain bisa digunakan } \\
\text { selama } 3 \text { hari }\end{array}$ & $63(70.8 \%)$ & $26(29.2 \%)$ \\
\hline 9. & $\begin{array}{l}\text { Tidak perlu mencuci masker } \\
\text { kain yang dibeli sebelum } \\
\text { dipakai, karena dalam kemasan } \\
\text { plastic }\end{array}$ & $74(83.1 \%)$ & $15(16.9 \%)$ \\
\hline
\end{tabular}

Menurut Arikunto (2010) pengetahuan seseorang dapat diketahui dan diinterpretasikan dengan skala yang bersifat kualitatif, yaitu baik, bila subyek 
menjawab benar 76\%-100\% seluruh pertanyaan. Cukup, bila subyek menjawab benar 56\%-75\% seluruh pertanyaan dan kurang, bila subyek menjawab benar $<56 \%$ seluruh pertanyaan. Jika dilihat dari pengukuran tersebut, pengetahuan masyarakat Medan Johor pada 9 (sembilan) item pertanyaan dapat dikategorikan baik.

Faktor yang mempengaruhi pengetahuan erat kaitannya dengan latar belakang pendidikan, dimana diharapkan bahwa dengan pendidikan yang tinggi maka orang tersebut akan semakin luas pula pengetahuannya. Sejalan dengan data demografi yang mayoritas adalah berpendidikan Diploma/Sarjana.

Faktor internal lain yang dapat mempengaruhi pengetahuan adalah pekerjaan dan usia (Notoatmojo). Pada hasil data didapatkan bahwa usia masyarakat yang dijadikan sampel mayoritas pada rentang remaja akhir (17-25 tahun). Pada usia remaja, akhir tingkat kematangan dan kekuatan sudah berkembang. Kematangan tersebut yang dapat mempengaruhi remaja dalam mencari informasi yang benar tentang covid-19. Bertambah usia berkembang pula daya tangkap dan pola pikirnya sehingga akan lebih mampu menerima dan menganalisa pengetahuan atau informasi yang baik

Dari 10 item pertanyaan, terdapat 1 (satu) pertanyaan yang kategori cukup (pertanyaan no.9) yaitu $29.2 \%$ menjawab salah pada pertanyaan masker kain bisa digunakan selama 3 hari. Tim Komunikasi Publik Gugus Tugas Nasional Percepatan Penanganan COVID-19 mengatakan semua pihak wajib memakai masker selama masa pandemi COVID-19. Ada 3 jenis masker, masker kain, masker bedah, dan masker N95. Masker kain yang direkomendasikan adalah masker yang memiliki 3 lapisan kain. Lapisan pertama adalah lapisan kain hidrofilik seperti katun, kemudian dilapisi oleh kain yang bisa mendukung viltrasi lebih optimal. Untuk lapisan kedua ini bisa juga menggunakan katun atau polyester. Lapisan ketiga atau bagian masker paling luar menggunakan lapisan hidrofobik atau bersifat anti air seperti terbuat dari polypropylene.

Masker kain harus dicuci jika akan dipakai kembali. Masker kain dapat dipakai maksimal hanya 4 jam dan harus ganti dengan masker baru dan bersih. Apabila masker yang dipakai basah atau lembab harus segera diganti. Masyarakat disarankan membawa beberapa masker untuk beraktivitas, penggunaan maskerpun harus tepat seperti menutup hidung dan mulut.

\section{PENUTUP}

\section{Simpulan}

Masyarakat sangat antusias dan senang dengan kegiatan yang dilakukan dan berharap kegiatan seperti ini tetap dilakukan selama pandemi covid ini sehingga dapat mengantisipasi pencegahan penyebaran covid-19.

\section{Saran}

Melihat antusiasnya masyarakat dalam kegiatan, maka diharapkan kegiatan sejenis yang dapat mencegah penyebaran covid-19 tetap dapat dilakukan seperti sosialisasi adaptasi kebiasaan baru. 
Wardiyah Daulay, dkk.: Pemanfaatan Kain Perca untuk Pembuatan Masker Kain (MAIN) Anti Virus dalam Rangka Pencegahan Virus Covid-19 Pada Rumah Jahit Sekitaran Medan Johor

\section{UCAPAN TERIMA KASIH}

Terima kasih yang setulusnya kepada yang terhormat Rektor Universitas Sumatera Utara, Ketua Lembaga Pengabdian Pada Masyarakat Universitas Sumatera Utara, Mitra Pengabdian Rumah Jahit Sania, masyarakat yang telah menjadi partisipan dan semua pihak yang tidak bisa disebutkan satu persatu yang telah membantu dalam kegiatan pengabdian ini.

\section{DAFTAR PUSTAKA}

Amri, Sofan. Iif Khoiru Ahmadi. (2010). Proses Pembelajaran Kreatif dan Inovatif Dalam Kelas: Metode, Landasan Teoritis-Praktis dan Penerapannya . Jakarta: PT. Prestasi Pustakaraya

Arikunto, S. (2010). Prosedur Penelitian Suatu Pendekatan Praktik. Jakarta: Rineka Cipta

Kemenkes RI. (2020). Pedoman Kesiapsiagaan Menghadapi Coronavirus Disease COVID-19) diunduh dari https://www.kemkes.go.id/resources/download/infoterkini/COVID9\%20dokumen\%20resmi/2\%20Pedoman\%20Pencegahan\%20dan \%20Pengendalian\%20Coronavirus\%20Disease\%20(COVID-19).pdf

Kemenkes RI. (2020). Pemakaian Masker Kain Yang Benar. Diunduh dari https://www.kemkes.go.id/pdf.php?id=200609000

Notoatmodjo S. (2012). Promosi Kesehatan dan Perilaku Kesehatan. Jakarta: PT Rineka Cipta

Pemerintah Kota Medan.(2020). Profil Medan Johor. https://pemkomedan.go.id/halmedan-johor.html

Rafiqua. (2020). Cara membuat masker efektif. Diunduh dari https://www.sehatq.com/artikel/wajib-pakai-saat-ke-luar-rumah-begini-caramembuat-masker-kain-yang-efektifNurulRafiqua, 2020 